\title{
Climate Change in The AlPine ZONe: A CONTINUOUS, MULTI-PROXY RECORD OF HOLOCENE GLACIER ACTIVITY AND ENVIRONMENTAL CHANGE AT Grand Teton National Park
}

\author{
DARREN J. LARSEN $\uparrow$ SARAH SPAULDING $\downarrow$ INSTAAR \\ UNIVERSITY OF COLORADO AT BOULDER $\downarrow$ BOULDER
}

\begin{abstract}
$\downarrow \quad$ AbSTRACT
Alpine environments are particularly sensitive to climate fluctuations and recent changes to their hydrological and ecological components have been documented in mountain ranges around the world. Paleoclimate reconstructions from these regions can improve our understanding of alpine climate change by placing recent observed changes in a long-term context and by improving our ability to accurately predict and model future changes. This research is designed to use lake sediments to reconstruct the glacier history and paleohydrology of the Teton Mountain ecosystem to provide a framework for characterizing the impacts of climate change occurring in Grand Teton National Park. Multiple physical and geochemical parameters contained in sediments from lakes strategically positioned along elevation transects will be used to develop the first continuous records of: 1) alpine glacier fluctuations, including the timing and character of deglaciation, and 2) coupled fire, vegetation and hydroclimate histories spanning the elevation gradient of the Tetons. This work is critical for assessing and managing the ecological impacts of future climate change in this unique ecosystem and for improving our understanding of how changes here are connected to the broader climate system.
\end{abstract}

\section{$\downarrow \quad$ INTRODUCTION}

The impacts of modern climate change on natural environments pose serious challenges for the National Park Service resource conservation efforts. Among the most vulnerable of National Park lands are the abiotic (e.g. hydrologic, glacial) and ecologic components of mountain ecosystems, where evidence for climate change impacts are numerous and include disappearing alpine glaciers, mountain pine beetle infestations, and reduced biodiversity. Mountain regions have been identified as particularly sensitive to climate changes (Fischlin, 2007), and it is likely that the observed impacts of current and future changes will be proportionally more apparent at higher elevations (e.g. Beniston et al., 1997). For these reasons, National Parks that contain alpine environments are ideal sites for research dedicated to the assessment of climate change impacts and their context within the range of natural variability. This work is designed to reconstruct the timing and magnitude of alpine climate variability at Grand Teton National Park (GRTE), and to assess the glacier and environmental responses to such variations.

The Tetons occupy a strategic position with respect to the climate dynamics of the western U.S. and GRTE contains a relatively pristine and intact ecosystem. However, despite the importance and sensitivity of this geographical region, few climate records exist. The majority of paleoclimate research efforts in the Teton Range have focused on the deglacial history of the area (Licciardi and Pierce, 
2008; Pierce et al., 2011) or on the dynamics of small extant alpine glaciers (Fryxell, 1935; Edmunds et al., 2011; Reynolds, 2011). Here, we will use lake sediments from basins positioned along three elevation transects to produce complementary, highresolution records of Holocene glacier activity and environmental change. The combined records will be studied to evaluate glacial and vegetative responses to global (and local) climate forcing mechanisms operating since regional deglaciation, with particular attention paid to the behavior of climate indicator proxies during the past 200 years. Once constrained, variability in the proxy records will be used to evaluate the evolution of Holocene climate since deglaciation of the Teton Range.

\section{$\uparrow \quad$ STUDY AREA}

Grand Teton National Park is one of the most visited National Parks in the country, attracting more than 2 million people every year (www.nps.gov). At the heart of the $\sim 485 \mathrm{mi}^{2}$ park stands the Teton
Mountain Range, a rectangular ( $\sim 40$ miles long by $\sim 10$ miles wide) fault-block mountain range flanked on both sides by broad, low-lying basins (Love et al., 2003). The unique tectonic setting and glacial history of GRTE has created a series of glacially carved, Ushaped valleys situated on the eastern flank of the range (Figure 1A). Many of the valleys contain a chain of lakes composed of multiple small basins, positioned in high elevation glacial cirques, which drain into a large, moraine-dammed piedmont lake at the valley mouth (Figure 1B). Lake basins at GRTE formed following regional deglaciation $\sim 15,000$ years ago (Licciardi and Pierce, 2008). Sediment fill in each lake marks the timing of glacier retreat from individual basins (lake inception) and contains a continuous and datable record of subsequent upstream glacier activity and environmental conditions in the catchment. This study focuses on three valleys: Avalanche Canyon, Glacier Gulch, and Cascade Canyon (Figure 1). Each valley spans $>3,000$ vertical feet of elevation and transects multiple vegetation environments from high alpine tundra down to mixed conifer forests at the valley floor.

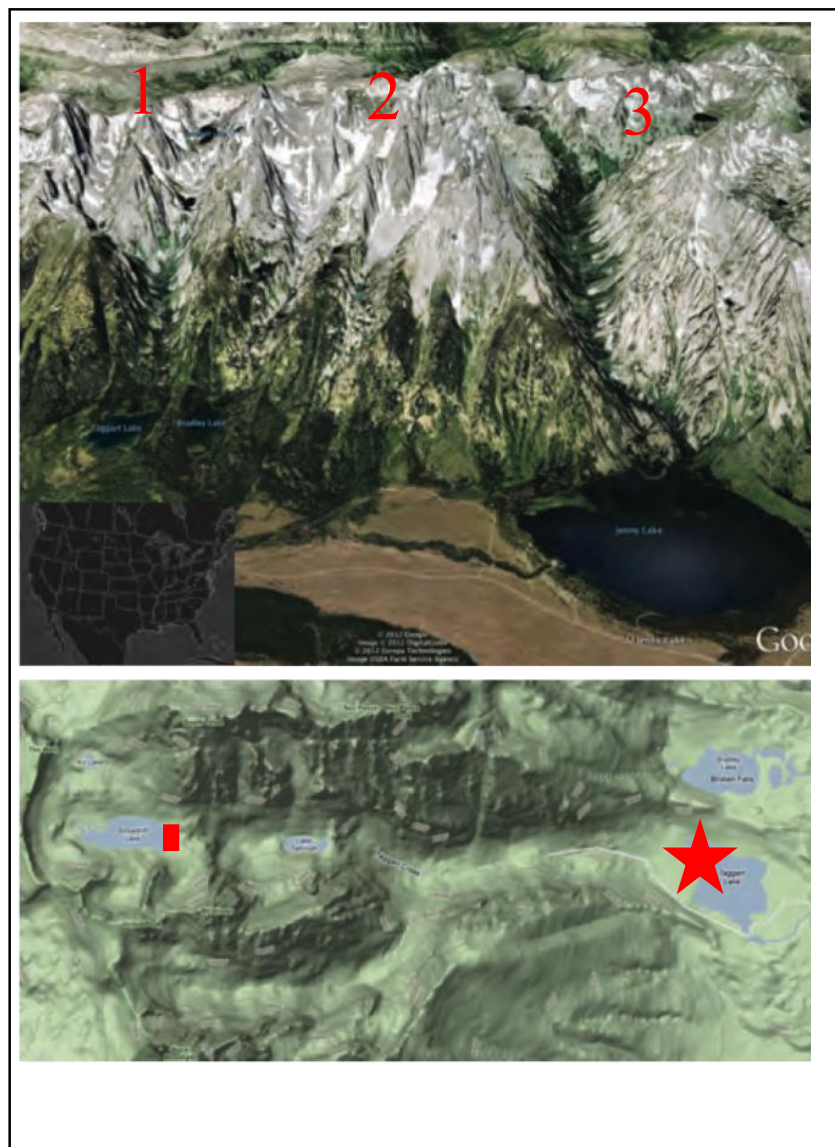

Figure 1. Location of field site at GRTE. (A) Oblique aerial view of the eastern flank of the Teton Range. The three valleys (and respective lakes) included in this study are numerically labeled in red. From south to north: 1) Avalanche Canyon (Taggart Lake, Lake Taminah, Snowdrift Lake), 2) Glacier Gulch (swampy meadow, Delta Lake), 3) Cascade Canyon (Jenny Lake, Lake Solitude, Mica Lake). Inset map highlights location of field site within U.S. (B) Aerial view of Avalanche Canyon showing typical chain of alpine lakes targeted for this project. Note multiple small, high elevation lakes that are positioned in glacially scoured cirque basins. These lakes drain down valley into Taggart Lake (red star). The large terminal moraine complex visible on the right side of the frame impounds Taggart Lake and marks the greatest extent of the valley glacier during the most recent (Pinedale) glaciation.

Avalanche and Cascade Canyons no longer contain glacier ice and sediment cores taken from lakes in these valleys will be used to develop 
complementary deglacial chronologies and paleohydrologic records. Glacier Gulch is a steeply dipping canyon that emanates from the clearly observable cirque below the north face of the Grand Teton. At the head of this canyon lies the Teton Glacier, one of the few existing glaciers in the Teton Range and a significant icon of GRTE. Recent glaciological studies have shown that Teton Glacier is sensitive to climate change and has fluctuated in area and volume in response to $20^{\text {th }}$ century climate variability (Edmunds et al., 2011; Reynolds, 2011). The terminal moraine at the base of Glacier Gulch surrounds a swampy meadow (bog) that represents the position of an ancient lake. It is likely this feature was once analogous to the piedmont lakes (i.e. Taggart Lake, Jenny Lake) included in this study. However, the basin has since been infilled with sediment produced by the activity of Teton Glacier. Sediment cores retrieved from Glacier Gulch will provide a continuous record of Teton Glacier activity and address lingering questions regarding its Holocene history (such as whether or not it completely disappeared during the early Holocene and what was the timing of its reformation and behavior during Neoglaciation).

\section{$\downarrow$ METHODS}

\section{Field Program}

Fieldwork was initiated in July 2012 and included reconnaissance of potential field sites, bathymetric mapping, seismic surveys, and lake coring. This work was made possible through a 2012 UW-NPS research grant. Summer field operations were based out of the UW-NPS Research Center, which provided fast and convenient access. Bathymetric mapping of the two piedmont lakes, Taggart and Bradley, was accomplished using a portable GPS based "fishfinder" device strapped to a hard-shell sea kayak that was generously lent to us by Dr. Hank Harlow and the UW-NPS research center. Depth soundings were recorded along a grid paddled on each lake surface and bathymetric maps were created by interpolation of the point datasets. Two subsequent summer field excursions to GRTE took place in August and October 2012, respectively. The purpose of these trips was to evaluate the access to high elevation lake sites and assess potential hazards related to approaching these sites in winter conditions with coring equipment and a team of field assistants.

Seismic surveys were conducted on Jenny and Taggart lakes using an EdgeTech sub-bottom profiler (CHIRP) to map the spatial distribution of sediment and to identify optimal coring locations. Seismic reflection data was collected along transects performed in a gridded manner covering the lake surface area and each transect was obtained in conjunction with a differential GPS device to record spatial coordinates. Sediment cores were retrieved from Taggart, Bradley, and Jenny Lakes during three coring campaigns between January and May 2013. All cores were retrieved from a stable ice platform on the lake surface using a percussion coring system (Nesje, 1992). In addition, a short surface core was taken from each lake to capture the sediment water interface and undisturbed upper sediments.

\section{Geochronology}

Establishing an accurate and reliable geochronology is a critical step in the development of useful paleoclimate records. Age control of the sediment cores will be obtained through a combination of radioisotope analysis and tephrochronology. Surface sediments and those deposited within the past ca. 100 years will be dated using short-lived isotopes $\left({ }^{137} \mathrm{Cs}\right.$ and $\left.{ }^{210} \mathrm{~Pb}\right)$ while older sediments will be dated using radiocarbon on terrestrial macrofossils. The radiometric-derived chronologies will be augmented by the presence of volcanic ash (tephra) deposits from known volcanic eruptions. Multiple Holocene tephra layers have been noted in nearby lake records (Whitlock, 1993; Spaulding et al., 2011) and have been discovered in extruded cores taken in this study (see results section below). Geochemical identification of all tephra layers will be achieved through electron probe microanalysis. The tephrostratigraphy at GRTE will improve the geochronology of this study by providing chronostratigraphic marker horizons and additional absolute age constraints.

\section{Analytical Program}

We will use radiocarbon to date basal sediments from the piedmont lakes and bog to time the initial recession of glacier ice from respective terminal moraines and use basal ages from high-elevation lakes to provide a succession of constraints on glacier size and rate of recession. Sediment physical characteristics (accumulation rate, magnetic susceptibility (MS), density, grain size) are primarily influenced by the contribution of glacially eroded material (Dahl, et al., 2003) and will be analyzed to track upstream glacier behavior throughout phases of retreat in neighboring valleys. Whole-core density and MS measurements will be taken in 0.5 to $1.0 \mathrm{~cm}$ intervals using a gamma-ray attenuation porosity evaluator (GRAPE) logging system. Core segments will then be split, and core halves photographed using 
a CoreScan flatbed scanner. Grain size analyses will be conducted at 1 to $20 \mathrm{~cm}$ resolution using a Malvern Long Bed Mastersizer and sediment accumulation rates will be determined from the individual chronologies established for each basin.

Charcoal accumulation and pollen assemblages preserved in lake sediments reflect biomass burning and vegetation type, respectively, and can be efficiently measured (Whitlock, 1993; Power et al., 2008; Power et al., 2011). Hydrologic and ecologic changes reflect variations in regional atmospheric circulation and are recorded by bulk biogeochemical properties (e.g. TOC, BSi, C:N, $\delta^{13} \mathrm{C}$ ) and in the hydrogen isotope ratios (D/H) of lipids (e.g. $n$-alkanes) and other molecular biomarkers from aquatic and terrestrial organic matter that are preserved in lake sediments (Meyers and Teranes, 2001; Huang et al., 2002; Sachse et al., 2004; Tierney et al., 2010). We will measure these hydrologic indicators in addition to charcoal and pollen taxa along each valley transect to develop coupled hydrology, fire, and vegetation histories at various elevations.

Sedimentary organic matter $(\mathrm{OM})$ proxies are commonly used indicators of environmental change and reflect changes in the productivity of lakes and their surrounding catchments (Meyers and Teranes, 2001). Climate changes are reflected in OM content through water temperature and lake- ice duration, or through changes in water column nutrient cycling and sediment delivery processes. Traditionally, total organic carbon (TOC) is used as a measure of withinlake primary productivity (Meyers and Teranes, 2001). However, in glacier occupied watersheds, TOC can be influenced by the influx of glacially derived clastic material (e.g. Larsen et al., 2011). Biogenic Silica (BSi) is an amorphous form of silica that is biogenically precipitated in the water column by a variety of aquatic organisms. In lake sediments, it primarily encompasses diatom frustules (Conley and Schelske, 2002) and like TOC, can be a reliable measure of primary productivity. Both TOC and BSi have been shown to correlate strongly with Holocene climatic changes, notably summer temperature (Battarbee et al., 2002; McKay et al., 2008). Lake sediment $\mathrm{OM}$ is derived from both terrestrial and aquatic sources. The abundance ratio of $\mathrm{C}: \mathrm{N}$ and $\delta^{13} \mathrm{C}$ will be used to evaluate changes in the source and production of vegetation growing in and around lakes. A major advantage of these proxies, relative to TOC and $\mathrm{BSi}$, is that they are relatively independent of sedimentation rate. All bulk biogeochemical indicators will be sampled for at 1 to $5 \mathrm{~cm}$ resolution.

\section{$\downarrow \quad$ PRELIMINARY ReSUlts}

\section{Seismic Surveys}

Preliminary results from the seismic surveys indicate large variations in the distribution and thickness of sediment related to the complex lake floor morphologies and dynamic history of lake sedimentation. The seismostratigraphy of Taggart Lake is faintly resolved and acoustically opaque, suggesting a high sand or clay content. Isolated pockets of laminated sediment packages are evident in deeper regions and near the base of a prominent ridge feature. These areas will be targeted in the coring program. The sediment in Jenny Lake has a stratified appearance and contains multiple strong seismic reflectors (Figure 2). Approximate sediment thickness ranges from $<0.5 \mathrm{~m}$ to $>5.0 \mathrm{~m}$. Multiple acoustically transparent ridges are visible in the seismic profile and are draped with sediment. These ridges are interpreted as recessional moraines built by the Cascade Canyon glacier during deglaciation ca. 14,000 years ago. Multiple strong seismic reflectors can be traced across the basin. The strongest reflectors are present in the bottom part of the sediment fill and are interpreted as dense, glaciolacustrine deposits. A few distinct reflectors, which are evident in the central sub-basin are absent in more distal sub-basins. The seismostratigraphic pattern will be used in conjunction with lake cores to unravel the character of deglaciation of Jenny Lake.

\section{Sediment Cores}

Cores were collected from multiple sites within each lake basin and range in length from $40 \mathrm{~cm}$ to $287 \mathrm{~cm}$. A total of eight, seven, and four cores were retrieved from Jenny, Taggart, and Bradley Lakes, respectively. At least one core from each lake contains light grey clay-rich basal sediments. These sediments are interpreted as deglacial deposits and confirm complete recovery of the Holocene sediment package. The depth to this clay layer in Jenny Lake corresponds to a distinct acoustic reflector seen in the seismic profiles at roughly $250 \mathrm{~cm}$ depth. Efforts to establish a secure geochronology for the lake sediments are currently underway. Two tephra layers were observed in an extruded core and sampled in the field for geochemical analysis. These layers were found at depths of $\sim 100$ and $\sim 150 \mathrm{dm}$ in a core taken 


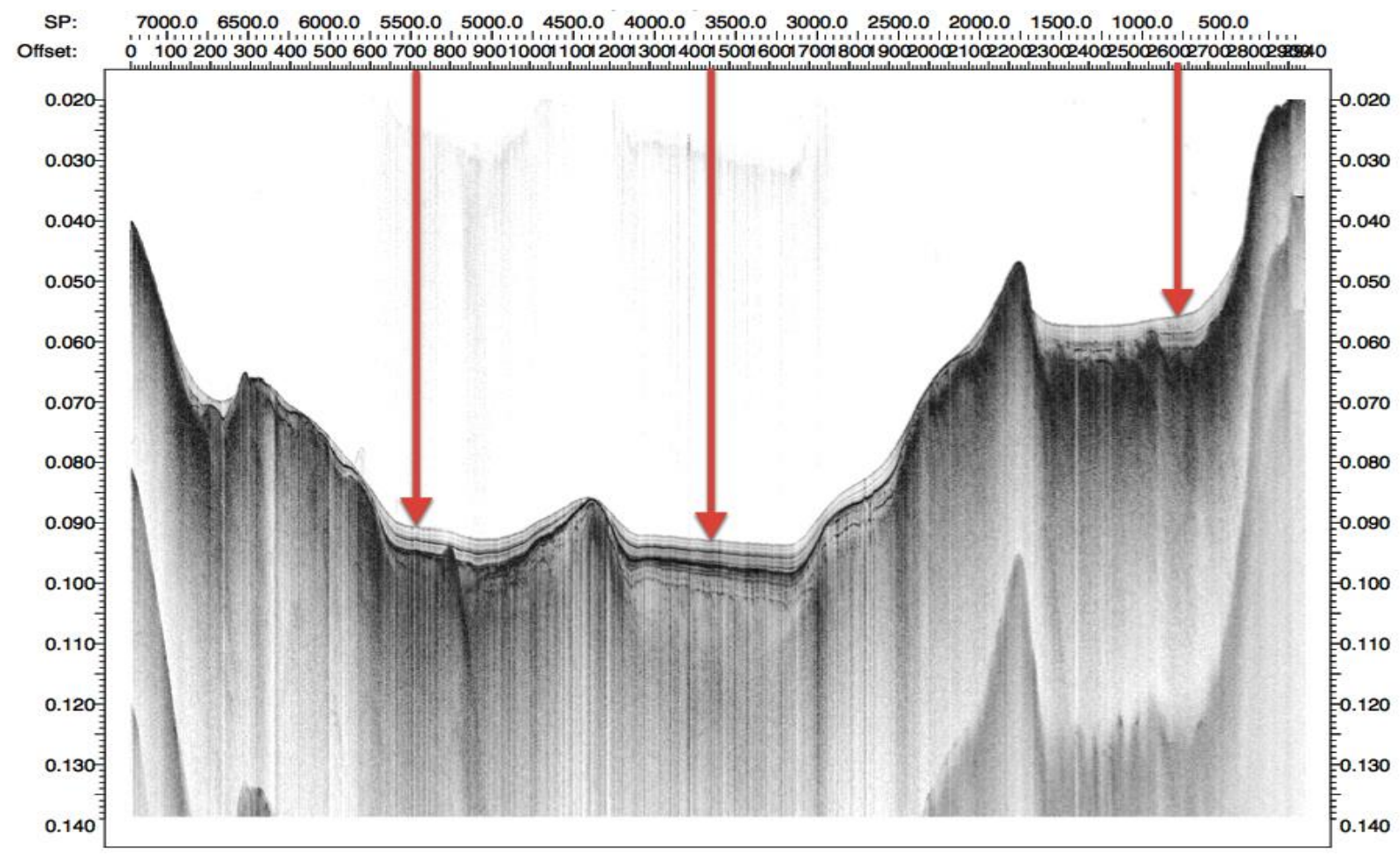

Figure 2. Seismic profile across Jenny Lake showing regular undisturbed lacustrine sediment fill interrupted by multiple recessional moraine ridges. This transect was performed in October 2012 using a CHIRP sub-bottom profiler. Lake core sites are shown (red arrows).

from Jenny Lake, and tentatively identified as the Mazama ( 7.6 ka) and Glacier Peak ( 13.6 ka) ash layers in accordance with nearby lake records (Whitlock, 1993). Both tephra samples have been sent to the University of Alberta for electron probe microanalyses and geochemical identifications are pending.

\section{Anticipated Results and Discussion}

The expected outcomes from this study will contribute to the understanding of past climate dynamics that have occurred in alpine environments of the western U.S. by providing a complete record of glacial fluctuations and complementary hydroclimate changes at GRTE, including the elevation effects of ecosystem responses to these changes. The implications for determining future changes to the Teton Mountain ecosystem resulting from natural and human-induced effects on the climate system are significant. In particular, empirical data and results from this work may improve the accuracy of predicting vegetation shifts, hydrologic (e.g. soil moisture, winter snowpack, lake water quality) changes, and ecosystem health. For example, we predict that intervals of higher-than-present summer temperatures in the past, such as those documented in the early Holocene, would have reduced moisture availability, induced changes in vegetation, increased burning frequency, and caused earlier snowmelt. If documented, such changes will likely serve as analogues for the future. The continuous deglacial chronology established through this effort will define early Holocene climate variability in the Tetons. Furthermore, results from this work will contribute to our understanding of the climatic and non-climatic forcing mechanisms behind alpine glacier fluctuations and will both complement and reduce the uncertainties of existing moraine dating methods (e.g. refine local ${ }^{10} \mathrm{Be}$ production rates).

\section{ACKNOWLEDGEMENTS}

This work has been completed in cooperation with GRTE NPS personnel and we offer thanks to Sue Consolo-Murphy (Chief Resource Manager), Kathy Mellander (GRTE GIS specialist), Scott Guenther (Jenny Lake Subdistrict Ranger), Tracy Stephens (Wyoming Game and Fish Dept.) and others who have lent assistance. We also thank Dr. Hank Harlow and the folks at the UW-NPS research center for financial 
and logistical support of this project. This project has received key support from the Grand Teton Association and the Explorers Club.

\section{$\uparrow$ Literature Cited}

Battarbee RW, Grytnes JA, Thompson R, Appleby PG, Catalan J, Korhola A, Birks HJB, Heegaard E, Lami A. 2002. Comparing palaeolimnological and instrumental evidence of climate change for remote mountain lakes over the last 200 years. Journal of Paleolimnology 28:161-179.

Beniston M, Diaz HF, Bradley RS. 1997. Climate change at high elevation sites: an overview. Climate Change. 36:233-251.

Conley DJ, Schelske CL. 2002. Tracking environmental change using lake sediments terrestrial, algal, and siliceous indicators. In: Smol JP, Birks HJB, Last WM, Bradley RS, Alverson K, editors, Developments in paleoenvironmental research. Springer Netherlands. p. 281-293.

Dahl SO, Bakke J, Øyvind L, Nesje A. 2003. Reconstruction of former glacier equilibrium-line altitudes based on proglacial sites: an evaluation of approaches and selection of sites. Quaternary Science Reviews 22:275-287.

Edmunds J, Tootle G, Kerr G, Sivanpillai R, Pochop L. 2011. Glacier variability (1967-2006) in the Teton Range, Wyoming, United States. Journal of the American Water Resources Association JAWRA 1-10. 48(1):187-196.

Fischlin A Midgley, GF Price, JT Leemans, R Gopal, B Turley, C Rounsevell, MDA, Dube OP, Tarazona J, Velichko AA. 2007. Ecosystems, their properties, goods, and services. In: Parry ML, Canziani OF, Palutikof JP, van der Linden PJ, Hanson CF, editors. Climate Change 2007: Impacts, Adaptation and Vulnerability. Contribution of Working Group II to the Fourth Assessment Report of the Intergovernmental Panel on Climate Change, Cambridge University Press, p. 211272.

Fryxell FM. 1935. Glaciers of the Grand Teton National Park of Wyoming: Journal of Geology 43(4), p. 381-397.
Huang Y, Shuman B, Wang Y, Webb T. 2003. Hydrogen isotope ratios of palmitic acid in lacustrine sediments record late Quarternary Climate Variations. Geology 30:1103-1106.

Larsen DJ, Miller GH, Geirsdóttir Á, Thordarson T. 2011. A 3000-year varved record of glacier activity and climate change from the proglacial lake Hvítárvatn. Quaternary Science Reviews 30:2715-2731.

Licciardi JM, Pierce KL. 2008. Cosmogenic exposureage chronologies of the Pinedale and Bull Lake glaciations in greater Yellowstone and the Teton Range, USA. Quaternary Science Reviews 27:814-831.

Love DJ, Reed Jr. JC, Pierce KL. 2003. Creation of the Teton Landscape: A Geological Chronicle of Jackson Hole and the Teton Range. Grand Teton Natural History Association, Moose, WY. 132pp.

McKay NP, Kaufman DS, Michelutti N. 2008. Biogenic silica concentration as a highresolution, quantitative temperature proxy at Hallet Lake, south-central AK. Geophysical Research Letters 35(5).

Meyers PA, Teranes JL. 2001. Sediment organic matter. In: Last WM, Smol JP, editors. Tracking environmental change using lake sediments, vol 2: physical and geochemical methods. Kluwer, Dordrecht. pp. 239-269.

Nesje A. 1992. A piston corer for lacustrine and marine sediments. Arctic and Alpine Research 24: 257-259.

Pierce KL, Muhs DR, Fosberg MA, Mahan SA, Rosenbaum JG, Licciardi JM, Pavich MJ. 2011. A loess-paleosol record of climate and glacial history over the past two glacialinterglacial cycles $\left(\begin{array}{lll}\sim 150 & \mathrm{ka}\end{array}\right)$, southern Jackson Hole, Wyoming. Quaternary Research 76:119-141.

Power MA, Marlon J, Ortiz N, Bartlein PJ, Harrison SP, Mayle FE, Ballouche A, Bradshaw RHW, Carcaillet C, Cordora C, et al. 2008. Changes in fire regimes since the latest glacial maximum: an assessment based on global synthesis and analysis of charcoal data. Climate Dynamics. 30:887-907. 
Power MJ, Mayle FE, Bartlein PJ, Marlon JR, Anderson RS, Behling H, Walsh MK. 2011. Climatic control of the biomass-burning decline in the Americas after AD 1500. The Holocene. 23(1):3-13.

Reynolds HA. 2011. Recent glacier fluctuations in Grand Teton National Park. Published M.S. Thesis, Department of Geosciences, Idaho State University. 225pp.

Saches D, Radke J, Geeixner G. 2004. Hydrogen isotope ratio of recent lacustrine sedimentary n-alkanes record modern climate variability. Geochimica et Cosmochimica Acta. 68:4877-4889
Spaulding SA, Otu M, Wolfe AP, Baron J. 2011. Atmospheric deposition of inorganic nitrogen in Grand Teton NP: determining biological effects on algal communities in alpine lakes. NPS annual research report, project number 119720 .

Tierney JE, James M. Russell, Hilde Eggermont, E. C. Hopmans, Dirk Verschuren, and Jaap S. Sinninghe Damsté. Environmental controls on branched tetraether lipid distributions in tropical East African lake sediments. Geochimica et Cosmochimica Acta 74, no. 17 (2010): 4902-4918.

Whitlock C. 1993. Postglacial vegetation and Climate of Grand Teton and southern Yellowstone National Parks. Ecological Monographs 63(2):173-198. 